\section{ECONOMICS}

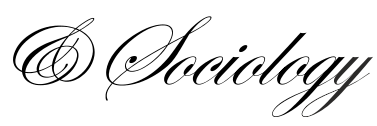

\title{
AN ANALYSIS OF SOCIAL PROXIMITY AND INTEREST RATE IN RURAL SOUTH INDIA
}

\author{
Augendra Bhukuth, \\ Ipag Business School and ITSMI \\ Ecole de Management, \\ Paris, France, \\ E-mail:augendra@gmail.com
}

Jérôme Ballet,

Université de Bordeaux,

Bordeaux, France,

E-mail:jballetfr@yahoo.fr

\author{
Katia Radja, \\ Université de Versailles-St Quentin \\ en Yvelines, $C E A R C$, \\ Université Paris Saclay, \\ Versailles, France, \\ E-mail:katia.radja@uvsq.fr
}

Received: September, 2017

1st Revision: December, 2017

Accepted: February, 2018

DOI: $10.14254 / 2071-$

789X.2018/11-1/10

JEL Classification:R10, I32,

\begin{abstract}
In this article we present the role of social proximity in the formation of the interest rate in the informal credit market in the state of Tamil Nadu, India. This paper is unique in the sense that it deals with social proximity and the formation of interest rate. If a lot of articles deal with the interest rate and social capital, none of them have attempted to link the two variables. A qualitative and quantitative survey was conducted on debt bondage in 2003-2004. The impact of social proximity defined as strong and weak is captured by a simple regression model. We show that a strong social proximity has a negative impact on the interest rate. Furthermore, the frequency of transactions has a positive impact on the interest rate, which means that asymmetrical information does not play a central role in our study. We then explain the relation between social proximity and interest rate by using the concept of rights and obligations.
\end{abstract}

Keywords: India; Social proximity; Social Capital; Interest rate; Poverty Indebtedness; Seasonal migrants.

\section{Introduction}

For many poor households, in the rural regions of developing countries, getting access to credit is an essential condition. This not only enables the financing of productive capital; thereby providing a means of getting out of poverty, but also provides the opportunity to smooth consumption. Very often, these households cannot get access to formal credit since they are not in possession of sufficient resources to serve as guarantee, a prerequisite to obtaining a credit (Hoff and Stiglitz, 1993).

Due to this situation, the governments of many developing countries have deployed efforts to facilitate the access of credit in the rural regions, either through the direct link of their state banks, or by the regulation of the commercial banks. For example, in India, the 
banking policy has come across different phases, each aiming at improving access to credit to rural populations (Ramachandran and Swaminathan, 2001).

Thus, in 1969 the government of India nationalised banks in order to encourage these institutions to promote access to bank credits to the rural population. This policy has led to an increase in the bank credits granted to land owners (whatever the size of their holding) at preferential interest rates (Basu, 2005). The aim of this policy is to modernise the rural sector, and to increase its growth rate. However, Chavan (2007) reports that access to the credit market by dalits decreased in the 1990s. Poor households, most of whom are landless, are denied access to the credit market because they have no savings and so do not have a bank account.

In such context, microfinance is an alternative way for poor people. The proclamation in 2005, by the General Assembly of the United Nations, of the international year of microfinance, and the Nobel Peace Prize awarded to Muhammad Yunus in 2006 for his work in this field, has highlighted this approach. However, microfinance does not fully solve the problem. Extremely poor households, particularly seasonal migrant households, have no access to microfinance (Churchill and Guérin, 2004).

We should not forget, however, that there are other ways of accessing credit. The informal credit market is one of them. This market offers a series of possible sources of credit that may take several forms, including "personal relationships" characterised by credit given to family members, loans from employers, and also credit given by shop owners, traders and wealthier people within the community to which the borrower belongs, etc.

The informal credit market is often considered as an exploitative market since interest rate is sometimes very high and always higher than in the formal credit market (Bottomley, 1963; Krishna et al., 2003), although, studies in rural India have found evidence of the existence of interest rates close to zero (Bardhan and Rudra, 1978; Guérin et al., 2007, 2004 and Bhukuth, 2006). The divergence of results on interest rate may emanate from the diversity of sources of credit in the informal credit market. Furthermore, it is also often segmented. (Nagarajan et al., 1995; Ghosh et al., 2000). The influence of certain variables on the interest rate on the informal credit market in India is then analysed. More specifically, on the basis of a study conducted in 2003 and 2004 in South India, we analyse the role that the two forms of social proximity (weak and strong) play in determining the interest rate in the informal credit market.

The rest of this paper is organised as follows: in the first section we relate the paper with the previous literature. In the second section we present the methodology. In the third section we present the main statistical facts about how the informal credit market is accessed. In the fourth section, the influence of social relationships on determining the interest rate is analysed, distinguishing between strong and weak social proximity. In particular, we show that lower interest is associated with strong social proximity.

\section{Literature review}

The informal credit market revolves around two main questions which are, on one side the existence of the market and, on the other side the understanding of the interest rates of this market.

The existence of the informal credit market is often analysed based on two alternative hypotheses: the existence of high transaction costs or the rationing of credit on the formal market.

The first hypothesis shows that the inhabitants of villages located in rural regions, due to the absence of formal credit institutions, are compelled to commute to the nearest towns 
where the formal credit institutions are located. Getting access to a credit may imply several trips and therefore infer high costs of transaction. For example, Giné (2010) estimates that the costs of transaction to have access to formal credit in Thailand may reach up to US \$130. The informal credit market reduces the costs of transaction due to the geographical convenience between borrower and lender. In the same study, Giné (2010) considers that nearly no transaction costs are implied on the informal market.

If it is clearly noted that there is insufficient access to formal credit in rural zones of developing countries (Braverman and Guash, 1986), government policies aiming at increasing access to credit to the populations of these zones have largely been developed. However, the expansion of formal credit in the rural zones has not significantly reduced the scale of informal credit (Timberg and Aiyan, 1980; Bell, 1990; Chakrabarty and Chaudhuri, 2001).

Therefore the hypothesis of costs of transaction is not sufficient. Based on the article of Stiglitz and Weiss (1981) on the adverse selection of the credit market, the second hypothesis analyses the existence of the informal credit market by using the phenomenon of rationing on the formal market. In asymmetrical information, formal financial institutions, in order to reduce portfolio risk and to reach a better composition constraint the borrowers. Households which are the most affected by rationing are those which cannot guarantee repayment, and therefore represent the least risks of repayment, in particular the poorest households. These households turn to the other financing mechanisms offered by the informal credit market. In this market, the relationships between lenders and borrowers allow lenders to get information on borrowers and to manage at best the risks; this does not mean that the informal credit market does not practice credit rationing ${ }^{1}$. However, the politics of government in developing countries have enabled the reduction of rationing, particularly through the expansion of non commercial banks. And as Kochar (1997) highlights in the case of India, credit rationing in the formal credit market is weaker than it is generally assumed.

These two hypotheses are not alternatives but rather complementary. Guirkinger (2008), in the case of Peru, shows for instance that the use of informal credit can be explained both by rationing in the formal market and high costs of transaction. Households actually use formal market or informal market for different reasons. Households who want to take loan for increasing the productive capacity and those who already possess some assets that they can pledge to reassure the lenders will use formal market. They then assume that transaction costs of the credit the want to receive is quite high and will allow accumulation of capital. Households who want a credit to smooth consumption, in the event they are experiencing a loss of income, must assure expenses of ceremonies or to face any shock, instead have recourse to the informal market. The planned expenses not being directly productive, households avoid having to pay more transaction costs.

The complementarity of both analyses allows us to understand that rich households, i.e. those possessing assets that can be offered as collateral, have at the same time used formal and informal market, whereas poorer households are excluded from formal market and only have recourse to informal market, which finally reduces their capacity to accumulate since credits in this market mainly concern credit for smoothing consumption. This finding has been demonstrated in several studies, for example Diagne (1999) in Malawi, Barslund (2007) in Vietnam or Krishna et al. (2003, 2004), Sriram and Parhi (2006), Bhukuth et al. (2007) in India.

Beyond the existence of informal credit market, the particularly high level of interest rate in this market has been one of the major issues (Bottomley, 1963; Krishna et al., 2003). Lenders in the informal market deal with households with greater difficulty of repayment and

\footnotetext{
${ }^{1}$ Zeller (1994) has shown that in Madagascar the informal credit market has also been experiencing a rationing
} linked mainly to households income. 
are rejected by the formal market, therefore, the interest rate constitute a premium for risk for lenders (Bottomley, 1963). Under such conditions, a policy aiming at promoting access to the formal market by offering cheap credits would provoke an adverse effect of composition which would degrade the terms of credit provided in the informal market, thereby increasing the interest rate on this market (Bose, 1998).

This premium of risk can be very high because of imperfect competition on the informal credit market where lenders may exert an influence on the rate (Nisbet, 1967; Aleem, 1990; Basu, 1991) $)^{2}$. At the hands of macro rationing on the formal market, lenders can also proceed to a micro rationing on the informal market. They propose a low level of credit at a very high interest rate at the first visit of a customer, then release the constraint as one goes along with contractual relationships provided any default of payment is found (Ghosh and Ray, 2001). Repeated interactions thus allow lenders to be acquainted with the clients and to personalize the transactions, so that the risk of default payment is reduced (Swaminathan, 1991). One of the characteristics of the informal credit market would be precisely the extent of personalisation of credit, thereby laying exclusively on long term relationships and with repeated credits (Ghosh et al., 2000).

However, not much emphasis has been laid on the role of the personalisation of transactions on the level of interest rates. This is precisely what is being dealt within this article.

Since Granovetter's work (1973), considerable studies have produced results corroborating the essential role of social networks in the labour market (see for instance and amongst others: Granovetter, 1982; Fischer, 1982; Marsden, 1987; Calvo-Armengol and Jackson, 2005; Wahba and Zenou, 2005). Several studies have also recently linked market conditions (notably price, and methods of repayment) to social relationships. For instance, van Bastelear and Leathers (2006) have studied the impact of social relationships on the repayment of seed loans among the joint liability groups in Southern Zambia, and have shown that trust generated by social relationship helps to reduce the transaction cost. Kirman and Vriend (2001) have shown, in the case of the fish market in Marseille [France], that the prices set on the market are linked to social relationships.

Leading on from this research, this article proposes to analyse interest rates in the informal market, and to relate this value to the social relationships between lenders and borrowers. In other words, it sets out to find to what extent interest rates in the informal credit market depend on social proximity. By social proximity we mean the degree of connection between people through relationships. The term 'social proximity' we use is different from that of social distance (Bhandari, 2007). Social distance measures the distance between people in terms of status, employment, cast and so on (objective characteristics) whereas social proximity just underlines the frequency of social interactions between people without taking into account the social distance. For instance, people from very different employment may be in touch frequently. This is the case of people who buy food to the grocery every day. They are in relation with the shopkeeper and may build a social proximity with him. Our concept of social proximity just underlines the subjective aspect of relationships.

More particularly we seek to determine whether social proximity is different from the reduction of asymmetrical information. According to Ghosh and Ray (2001) the frequency of transactions reduces asymmetrical information and thus affects the interest rate. We attempt to verify if the type of lenders exerts an influence independently to the frequency of transaction,

\footnotetext{
${ }^{2}$ A different but complementary analysis of the high level of interest rate in the informal credit market emanates from the role of corruption in the formal market. In the event applicants must pay a bribe to the officers who manage and provide credit for obtaining a credit on this market, then it makes sense that the interest rate may be high in the informal market (Gupta et Chaudhuri, 1997).
} 
and if the frequency of transactions exerts an influence on the interest rate. If on the one side, the frequency of transactions does not exert any influence to lower the interest rate, and on the other side the type of lender has an influence on the interest rate, then it can be inferred that social proximity is not reduced to knowledge of information but implies others mechanisms of social nature such as the rights and obligations of a community (Mahieu, 2001).

\section{Methodological approach}

\subsection{Data collection}

We surveyed 255 poor households in their villages, in the State of Tamil Nadu, in 2003-2004, no new research has been conducted in the state since now. Therefore, we are unable to present new data on debt bondage and the situation of households. The survey is not representative to the whole country. Several researches were carried out in Tamil Nadu in different industries (sugarcane industry, rice industry and others) to understand the mechanism of debt bondage, their effects on households' well-being. The state of Tamil Nadu is one of the most developed states in India, despite good economic performances poverty and debt bondage still prevails in Tamil Nadu. Individuals and households in the situation of debt bondage are bonded labourers. They take advances from maistries (labour brokers) in the villages and are compelled to work for the (maistries or the employers) to reimburse their debt. For more information on how the individuals are recruited and debt bondage takes place in rural areas in Tamil Nadu see for example (Bhukuth et al., 2006), Guérin et al., 2004). The research was conducted by the team of the French Institute of Pondicherry (FIP) was led by Isabelle Guérin was financed by the ILO and FIP (Guérien et al., 2004). The ILO is concerned with the issue of debt bondage and bonded labour in India. According to Guérin et al. (2012) the advance system is practiced by the construction and brick kiln industries to impose low wages and to control labourers. The study analyses the mechanism of getting trapped into debt bondage and the exploitative characteristics of bonded labour. The forces in action bonding people in rural areas and how to escape from the trap were the main interests of the research project. One of the aims of the research project was to study debt bondage and the role microfinance could play to eliminate this phenomenon.

As the study was on debt bondage a three-step survey was conducted in order to understand the phenomenon.

Firstly, a survey was carried out on debt bondage in brick kiln industries in the state of Tamil Nadu where we have identified the workers. Their address was asked. A systematic sample was used. However, since the workers were not free to express themselves on the site of production, and in order to obtain accurate information on their financial situation, working conditions, the relationship between labour brokers (maistries) and employers, the workers were surveyed in their respective villages located in the district of Villupuram in Tamil Nadu. The aim of this study was to analyse the financial and living conditions of people living in extreme poverty. Regular visits to the village were realised for identifying the brokers and the labourers. During the visits, the labourers have presented their teams and their peers. In total 211 households working in the brick kiln accepted to be part of the study and were surveyed. This sample represents $25 \%$ of the total families in 10 villages and it covered all communities and the length of their job involvement (Bhukuth et al., 2016).

At the second stage of the study we used qualitative and quantitative methods to explore all aspect of these households. For the qualitative study an open questionnaire was 
used. Heads of households were interviewed both collectively (focus group survey ${ }^{3}$ ) and individually. To avoid gender bias, the head was interviewed informally (qualitative survey) at the tea shop or at home after the work. The latter's information was cross checked with that of his wife to ensure the accuracy of the information gathered. The qualitative survey was intended to complement the quantitative questionnaire, and it gave the heads of households an opportunity to describe their situation in greater details, and to give more detailed arguments instead of just answering "yes" or "no" to a series of questions.

The third step consisted of designing a quantitative questionnaire with the information obtained from the villagers. Among the 255 households surveyed, 211 were seasonal migrants, the remaining 44 households are non migrant households. The 44 non migrant villagers were chosen randomly. Questions was asked on debt bondage, bonded labour, child labour, financial practices, living conditions. It was asked to the interviewees how much interest they pay for loan taken with different sources. For more detail on the question design, complete methodology of the research see for example Guérin et al. (2004). The financial practices were the main concern of the study as it is linked with debt bondage. The financial aspect of the study revolved around the borrowing practices of households, their saving habits, and also their lending practices. In this paper, we consider the quantitative and qualitative evidence together, in an attempt to determine the importance of social proximity in determining interest rates.

\subsection{Financial sources in the villages}

As Bhende (1986) underlines, sources of credit vary according to villages. In the village we surveyed, there are several different potential sources of finance (formal and informal) from which households may borrow. This means that they can borrow from different sources for their different expenses, thus accumulating debt. But in the end they will have to repay all their debts. There are at least nine sources of finance available in the village: relatives/friends, maistries (labour brokers), shopkeepers or shop-owners (grocery shop/ vessel shop), wealthier individuals within the village, moneylenders, pawnbrokers, and a bank. As we are only concerned with informal sources of credit we have ignored the bank. Microfinance is expanding all around India and such institutions are now offering their services to poor households, but some households, such as those surveyed in this sample, have no access to these financial services. This has led us to eliminate 16 financial operations associated with microfinance and banks out of the total of 770 credit operations, leaving 754 informal credit operations.

We have divided the sources of finance into two groups: the first group corresponds to a strong social proximity, and it comprises relatives/friends, maistries and shopowners or shopkeepers. The second group of sources of finance consists of the wealthier individuals in the village, moneylenders and pawnbrokers. It constitutes the weak social proximity group. These groups are distinguished on the basis of the proximity of the relationship between borrowers and lenders. In the first group, the relationship between the lenders and the borrowers is very frequent, whereas in the second it is only restricted to financial transactions.

Maistries are the main source of credit for households. These brokers recruit seasonal labourers mainly to work in the brick kiln industry. The recruiting process is based on a system of advances. In this system, the broker lends money to the labourers he recruits, and in

\footnotetext{
${ }^{3}$ The aim of the focus group survey is to get an insight of the social relation of indebted households with the maistries, employers, and the villagers.
} 
exchange hires their labour. The labourers will then have to work for the broker for one season.

However, lending money to labourers is risky, and so to minimize the risk, brokers recruit labourers mainly from a close network: family members, neighbours, members of their own caste (Bhukuth et al., 2007). Brokers therefore actually recruit labourers over whom they have some control, and some financial and moral influence. But it is also risky for labourer taking loan from a broker. If the labourer is unable to repay the entire debt, he falls into debt bondage. This means that he has to work for the same broker again the next season, and he is not allowed to take any advance payment from any other maistry in the village. This system is basically the same as the phenomenon observed by Bhardan (1980) and Braverman and Stiglitz (1982) in the interlinked credit labour market in rural areas. The sole difference resides in the indirect aspect of the recruiting process. Households permanently in need of money prefer this system of credit ${ }^{4}$. To avoid falling into debt bondage, and to increase the possibility to be employ for the next season, labourers build strong relationships with the brokers (Bhukuth 2006 and Bhukuth et al., 2007).

The second source of finance within the strong social proximity group consists of relatives and friends. Households ask for small loans from their friends and relatives. If the amount borrowed is higher than expected the lenders charge the borrower interest, to compensate for the opportunity cost of lending. The interest rates imposed do not exceed 5\%. This finding is similar to other studies carried out by Krishna et al. (2003, 2004), and Sriram and Parhi (2006). These studies show that relatives and friends hide their wealth to avoid having to lend money to other members of their family and community. In our village, lending money circulates and is based on reciprocity. When a household has enough money to satisfy its expenses, it can lend to a family member who is in need, and may charge interest if the amount requested is higher than usual. The borrowing and lending relationship is based on reciprocity, which is justified by the fact that there is not enough employment for everyone in the village, and so anyone could need money. In these circumstances, people first turn to maistries and family members to satisfy their needs.

The last source of finance in the strong social proximity group is the shopkeepers and shopowners (Grocery shop/Vessel shop/Cloth merchant). The relationship with these sources of credit is quite strong, as the head of the households, their wives and even their children, all spend time in the shop buying goods and talking to other villagers. Shops are meeting places and sites of social life. Hence, the frequency of contact is high, and this is a factor creating trust relationships, and thus maintaining or even enhancing the social relationships with other villagers and with the shopkeepers and owners.

The weak social proximity group is comprised of the wealthier individuals in the village, moneylenders and pawnbrokers. Moneylenders are alternative sources of credit in rural villages. There are two kinds of moneylenders: professionals and non-professionals. The former have a good reputation among the villagers, whereas the latter are known for their misdemeanours, and have a bad reputation. The professional moneylenders are well known, established institutions. They have a licence to operate as moneylenders, which is not the case of the non-professional ones. In most cases, legal moneylenders operate from their shops, whereas the others roam from village to village to lend their money, and demand a higher rate of interest. Even when households maintain a good relationship with the professional moneylenders, their relationship remains mainly professional with regard to credit. The good relationship can give households some bargaining power about the interest rate and the delay of payment. Professional moneylenders adopt a flexible approach, depending on the situation

\footnotetext{
${ }^{4}$ For a complete analysis of the brokerage system, see Bhukuth et al. (2006).
} 
of the household (Guérin et al., 2004). Non-professional moneylenders do not do this, and if a debt is not repaid, they use physical violence and moral harassment to get their money back. For example, they may threaten the debtor at home, informing his neighbours about his situation, and complain to their family and panchayat. They may even be aggressive with the debtor (Guérin et al., 2004). In this case, there is obviously no social proximity between the non-professional moneylender and the villager. The former, who has saved some money, only thinks about making more money by lending to households who are deeply in need of money. These moneylenders do not ask for any guarantee, such as mortgaging assets, which tempts households who have very few assets to pledge. This contrasts with the behaviour of professional moneylenders and pawnbrokers, who guarantee against the risk of defaulting by adopting a flexible approach and asking for mortgaging assets. They have recourse to legal means to recover their money. The interest rate is bargained with the professional moneylenders and pawnbrokers, but this is rarely the case with non-professional moneylenders.

\section{Statistical facts and estimate results}

In this section, only the statistical findings which relate to the factors that have been taken into consideration, will be presented. A linear model (OLS) was used to estimate interest rate in relation with its explaining factors. In the model the predicates of the interest rate are: frequency of taking loan, social proximity and compounding debt. These explaining factors can influence the interest rate.

\subsection{The frequency of borrowing and the interest rate}

The table below describes the frequency of financial transactions realised by the interviewees. The table can be read as follows: for example 7 financial operations are realised on a weekly basis with relatives/friends. By the same token, the figures in the table correspond to demand for credits from different financial sources available in the village. The 255 households surveyed have been involved in 754 financial transactions with different financial sources.

The frequency of borrowing from different sources gives a good insight of the demand for loans. Table 1 shows that poor households take loan from financial sources "only once or twice a year", representing 328 financial operations and also "several times in a year" which represents 288 operations. When the frequency of taking loan is "several times per year" then mainly households borrow from maistries ( 82 financial operations recorded), pawnbrokers (85) and relatives (72). When the frequency is "Once or twice a year", households take loan from maistries (95), pawnbrokers (85) and "wealthier person of the village" (72). This frequency of taking loans from the maistries matches the findings of Bhukuth et al. (2006). Borrowing from moneylender and pawnbrokers "once or twice a year" signifies that these agents are not the main source of credit in the village. Hence, households do seek loans from their relatives more often (in a monthly basis for 43 credit operations, and several times a year in 73 cases). The household diversifies the sources of credit for not being dependant to only one source. Moreover the diversification of sources is part of logic of survival very carefully planned, in the sense that the household borrows from one source to pay another one. But the constraint is the household is permanently indebted. 
Table 1. Frequency of borrowing from different sources of credit

\begin{tabular}{|c|c|c|c|c|c|}
\hline \multirow[b]{2}{*}{ SOURCES OF CREDIT } & \multicolumn{4}{|c|}{ FREQUENCY } & \multirow[t]{2}{*}{ Total } \\
\hline & Weekly & Monthly & $\begin{array}{l}\text { Several times } \\
\text { per year }\end{array}$ & $\begin{array}{l}\text { Only once or } \\
\text { twice a year }\end{array}$ & \\
\hline $\begin{array}{l}\text { Relatives/Friends(In Tamil: } \\
\text { kaimathu) }\end{array}$ & 7 & 43 & 73 & 12 & 135 \\
\hline $\begin{array}{l}\text { Wealthy people in the } \\
\text { neighbourhood }\end{array}$ & 4 & 6 & 6 & 72 & 88 \\
\hline Money Lenders & & 10 & 18 & 55 & 83 \\
\hline Maistry & 2 & 24 & 82 & 96 & 204 \\
\hline Shopkeeper & 8 & 10 & 5 & & 23 \\
\hline $\begin{array}{l}\text { Grocery shop / Vessel shop / } \\
\text { Cloth merchant }\end{array}$ & 10 & 8 & 19 & 8 & 45 \\
\hline Pawnbroker(Adagu place) & 1 & 5 & 85 & 85 & 176 \\
\hline Total & 32 & 106 & 288 & 328 & 754 \\
\hline
\end{tabular}

\subsection{The outstanding debt}

Table 2 presents the number of financial operations realised with two sources of credit which we have categorised under the items strong and weak. These two sources of credit represent social proximity; strong means that social relations maintained by economic agents are strong and weak implies that social relations are weak. $\mathrm{N}$ represents the number of financial operations realised. 339 operations have been realised with lenders classified under the category of strong and 415 credit operations with lenders in the weak category out of a total of 754 credit operations. The table presents the mean of minimum and maximum credits provided by sources of credit (strong and weak) as well as the debt of households.

Households take only small loans from their relatives and friends, because they have limited funds and cannot lend too much. Households borrow more from wealthier individuals in the village, and from the maistries and pawnbrokers. Since the frequencies of taking loan from these sources are not high, this suggests that households only contract loans in exceptional circumstances, except in the case of the maistries.

Table 2. Social proximity and debt

\begin{tabular}{lrrrrrrr}
\hline \multirow{2}{*}{$\begin{array}{c}\text { SOCIAL } \\
\text { proximity }\end{array}$} & $\mathrm{N}$ & \multicolumn{2}{c}{ MIN AMOUNT } & \multicolumn{2}{c}{ MAX AMOUNT } & \multicolumn{2}{c}{ OUSTANDING DEBT } \\
\cline { 3 - 8 } & MEAN & $\begin{array}{c}\text { STANDARD } \\
\text { DEVIATION }\end{array}$ & MEAN & $\begin{array}{l}\text { STANDARD } \\
\text { DEVIATION }\end{array}$ & MEAN & $\begin{array}{c}\text { STANDARD } \\
\text { DEVIATION }\end{array}$ \\
\hline Strong & 339 & 1406,34 & 2838,75 & 4596,61 & 7020,27 & 4500,00 & 5657,52 \\
\hline Weak & 415 & 1201,05 & 2515,76 & 5406,14 & 7431,54 & 3771,67 & 5669,81 \\
\hline TOTAL & 754 & 1293,35 & 2665,97 & 5042,18 & 7255,96 & 4099,13 & 5672,12 \\
\hline
\end{tabular}

Taking consequent loans both from the strong social proximity and the weak social proximity groups does not enable households to avoid being indebted. On average, the outstanding debt is higher for the households who have borrowed from the strong social proximity group than from the weak social proximity group. They get indebted in the former group to the maistries, and in the latter group to the wealthier individuals in the village, who are mainly the local landlords. The consequence of having huge debt to these kinds of sources of finance is to be caught in debt bondage. In the case of being indebted to maistries, this involves the loss of their freedom to sell their labour and work seasonally for other maistries. 
The households can repay their debts by working for the maistry concerned. The risk of having huge debt with the moneylenders and pawnbrokers is that of losing the asset mortgaged. But as we have already seen, borrowers and lenders have established customary relationships, and the lenders usually deal with these situations by adopting a flexible approach. They either reduce the amount of credit granted, or the interest rate in order not to struggle the households.

In the case of 567 credit operations with an average debt of Rs 5,105, the interest rate was not compounded, whereas it was for 187 credit operations with an average loan of Rs1,048. The average debt incurred by most of the households remains unchanged, because they have learnt to manage the risk of indebtedness. In fact, the households are permanently indebted. They try to repay the debt by small instalments to give a positive signal to the creditors. This is the only way they can ensure a relationship of trust with their creditors. The indebted household also contract out loans from one creditor to pay back another one, and this process continues until they migrate to work. The main activity that enables them to repay their debt is working for the maistries as seasonal workers. These households can earn enough money, to accumulate material assets, and to repay their debt. Bhukuth et al. (2007) have shown that the probability of earning money from the seasonal activity depends on the maistry-labourer relationship.

\subsection{The relation between indebtedness and interest rate}

As shown in Table 2, the average outstanding debt is Rs. 4099,13, with a standard deviation of Rs. 5672,13. The discrepancy between the mean and the standard deviation is explained by the fact that some households borrow more than others.

The households that have contracted higher loans have huge debts, as they are unable to repay all their debts. A high level of debt is linked to the highest interest rate. Seven credit operations have an average loan of Rs.13,714, with a standard deviation of Rs.6,343, at a 15\% interest rate. The credit operations with a $15 \%$ interest rate were enacted with the wealthier people in the village (four credit operations), one with a moneylender, and two with pawnbrokers. The outstanding debt is also high at low interest rates (2 and 3\%). This is explained by the fact that as the interest rate is not high, households contract greater amount of loans. The highest loan received is Rs50,000.

\subsection{Relationship between interest rate and social proximity}

The table below presents the relation between interest rate and social relations. The average interest rate provided by lenders with whom the borrowers have a weak social relation is $4,54 \%$ whereas it is at $0,11 \%$ in the case of strong social relation. The interest rate is thus almost nil for credits borrowed from lenders maintaining strong social relationship with borrowers. The interest rates are negotiated on a weekly basis. The borrowers bargain for the interest rate with lenders. The payment of debt on a weekly basis becomes less constraining since the interest rate is low whilst being high on a monthly basis. For instance an interest rate of $5 \%$ weekly matches with $20 \%$ monthly. It is more constraining to pay a credit at $20 \%$ interest rate. The lender has the guarantee of being paid on a weekly basis rather than on a monthly basis.

We have assumed that the interest rate depends more on social relation. In other words, the stronger the social relation the lower is the interest rate and inversely. It is also assumed that the borrowers can bargain for preferential interest rate. It is easier to bargain with lenders who are closed to or with whom the borrower maintains proximity relations. 
At this stage two alternative hypotheses can be formulated. Either the relation of proximity reduces information asymmetry and the interest rate decreases due to the reduction of risk premium; or proximity relations get entangled in a system of rights and obligations (Mahieu 2001) and the weakness of the interest rate is explained from such a system. For instance, for exchange of preferential interest rates, the borrower could be in the obligation to work in the fields of lenders or to be available at any time required. The borrowers are perfectly informed of the fact that they would be driven to execute duties or work for the lender. These services provided allow the consolidation of proximity social relations. A person refusing to be subjugated would be in a social exclusion situation.

Fieldwork tends towards the second hypothesis and it's pertinence is verified in the following section.

Table 3. Interest rate and social proximity

\begin{tabular}{lccc}
\hline \multicolumn{1}{c}{ Social proximity } & Mean & $\mathrm{N}$ & Std. Deviation \\
\hline WEAK & 4,54 & 415 & 3,27 \\
\hline STRONG & 0,11 & 339 & 0,62 \\
\hline TOTAL & 2,55 & 754 & 3,31 \\
\hline
\end{tabular}

\section{Estimates of the interest rate in terms of social proximity}

In this section we test the relationship between the interest rate and social proximity. Social proximity is an explanatory factor for the interest rate. The model presented makes it possible to determine the factors that influence the interest rate presented in equation 3 above. We use a simple linear regression model. This model is relevant to understanding how the proximity of the relationship determines the interest rate. Social proximity is a binary factor, and can take the form of strong or weak social proximity. The hypothesis is that when the household is more often in connection with the lender this will reduce the interest rate, in other words, strong social proximity has a negative impact on the interest rate, and inversely, weak social proximity has a positive impact on the interest rate.

Social proximity (StrongSP) is a dummy variable taking the value 1 for strong relationship and 0 for weak relationship. The exogenous variables of the model are minimum of loan taken (min Amount), the frequencies of loan taken (Frequency) and the loan that has been compounded (CompoundinDebt). The latter variable is dummy variable taking the value 1 for Yes if the debt has been compounded and 0 if not. This variable takes into account whether the debt has increased. If the answer is Yes then it is considered that the debt is increased. In rural areas, households living in extreme poverty take small amount of amount in a high frequency. These variables influence the formation of the interest rate which is negotiated with the loan suppliers. The minimum amount of credit is taken as an exogenous variable for the simple reason that we want to test the dependant relation it can have on the interest rate. The borrowers take smaller amount of loan with lenders whose social proximity is strong. They may borrow several times with the same lender. Thus, it consists of determining the sign of the coefficient of estimation to capture the influence of this variable on the dependant variable. Stiglitz and Weiss (1981) explain that banks in information asymmetry fix a high interest rate to ration the credit. We can consider that a high amount of credit may increase interest rate to hedge against the risk. Inversely, a low interest rate may be associated with low credit.

The explaining variables are a mix of quantitative and qualitative variables. Two of the variables social proximity (strong and weak) and compounding are dummy variables. The 
other variables are quantitative (Frequency and min Amount). Therefore, a linear estimate model (OLS) is chosen instead of a logit model. Indeed if the explained variables were qualitative and specially a dummy variable the logit model would be chosen. As the interest rate is a quantitative variable the OLS model was chosen. The model shows the relationship between the independent variables and the dependent variables. It is interesting to understand the independent variables having an impact on the interest rate.

The model tested is as follows:

$$
i_{t}=\beta_{0}+\beta_{1} \text { StrongSP }_{t}+\beta_{2} \text { Frequency }_{t j}+\beta_{3} \min \text { Amount }_{t}+\beta_{4} \text { CompoundingDebt }_{t}+\varepsilon_{1}
$$

The index $\mathrm{t}$ in the model represents the period of transaction. The financial transactions were realised during a period of time $t$ which represents one year. Therefore, the variable "frequency" has a double index which indicates the different frequencies of credit taken during the time t. thus, $\mathrm{j}$ represents, weekly, monthly, several times a year, only once or twice a year.

Prior to testing this relation, the correlation between variables is verified. Table 4 of Pearson correlation shows that there is no correlation between exogenous variables. The explaining variables do not present any problem of endogeneity. They can be a predicate explaining the formation of interest rate.

Table 4. Pearson Correlation

\begin{tabular}{lrrrrr}
\hline & Rate of Interest & Minimum & Frequencies & Compounding Proximity strong \\
\hline Interest Rate & 1,000 & & & & \\
\hline Minimum &, 092 & 1,000 & & & \\
\hline Frequencies &, 318 &, 269 & 1,000 & & \\
\hline compounding &, 559 &,- 183 &, 179 & 1,000 & \\
\hline proximity strong &,- 668 &, 038 &,- 153 &,- 420 & 1,000 \\
\hline
\end{tabular}

The results of the regression model are then shown in Table 5 below. The explanatory variables of the model are all significant at $P \leq 0.05$. Indeed, the compounding debt has a positive impact on the interest rate. It means that when the household's debt situation has been worsen-off, the creditor increases the interest rate in order to limit the demand for credit. It has been stated that lenders adapt their behaviour according to the indebtedness of household, this hypothesis is confirmed by our estimates. Moneylenders, pawnbrokers and wealthy individuals in the village adopt a flexible approach, depending on the financial situation of the household.

Moreover, what emerges, therefore, is that the frequency of taking loans has a positive impact on the interest rate, which is significant. This variable explains why lenders try to limit the debtors to asking for credit in a regular way, because they are not able to repay their debt. The more they want to borrow, the higher the interest rate. Lenders want to avoid an overindebtedness situation, which is unsolvable both for the household and for the lender. What limits the request for credit is not the indebtedness situation of the household, but the frequency with which credit is requested and whether the situation has been deteriorated. This result contradicts the hypothesis of micro rationing of Ghosh and Ray (2001) who both state that the interest rate decreases with the frequency of transactions because the lender acquires information on the borrowers. Our result may suggest that the question of social proximity does not reduce the problem of asymmetry of information, but that others phenomena could be determinant, for example like the feeling of being more or less oblige to realise 
transactions according to social proximity. An effect of belonging to a community appurtenance could exist which could distinguish different types of lenders. Such a hypothesis could be assimilated to the notion of rights and obligations of economic anthropology (Mahieu, 2001).

Moreover, the amount of loan taken also plays an important role in the formation of the interest rate. In rural areas characterised by absolute poverty credit transactions are based on small amount on a short term basis. The accumulation of small amount of credit can lead to over-indebtedness. In fact, the minimum amount of loan has a positive impact on the interest rate. Indeed, households take small amount of loan several times per period. A positive high interest rate can have the effect of discouraging the demand for credit. It regulates the supply and demand for credit on the informal credit market.

The estimates indicate that strong proximity is significant and its estimate coefficient is negative. Hence, strong social proximity negatively influences the rate of interest, whereas weak social proximity has a positive impact on the interest rate. The hypotheses associated with the interest rate and social proximity are verified. In other words, since the borrowers know the lenders because of the social proximity then can bargain for lower interest rate. The lender and the borrower are committed in a reciprocal relationship.

Table 5. The results of the estimate

$\begin{array}{llllll}\text { Source } & \text { SS } & \text { df } & \text { MS } & \text { Number of obs } & =754 \\ & & & & \text { F ( 4, 749) } & =268.92 \\ \text { Model } & 4852.10106 & 4 & 1213.02526 & \text { Prob }>\text { F } & =0.0000 \\ \text { Residual } & 3378.58329 & 749 & 4.51079212 & \text { R-squared } & =0.5895 \\ & & & & \text { Adj R-squared } & =0.5873 \\ \text { Total } & 8230.68435 & 753 & 10.9305237 & \text { Root MSE } & =2.1239\end{array}$

\begin{tabular}{lcc}
\hline Interest rate & Coef. & $\mathrm{P}>\mathrm{t}$ \\
\hline \multirow{2}{*}{ Minimum Amount } & $\begin{array}{l}0001693 \\
(5.44)\end{array}$ & 0.000 \\
\hline \multirow{2}{*}{ Frequency } & $\begin{array}{c}5612783 \\
(5.66)\end{array}$ & 0.000 \\
\hline Compounding & $\begin{array}{c}2.644081 \\
(12.93)\end{array}$ & 0.000 \\
\hline Strong Proximity & $\begin{array}{c}3.36394 \\
(-19.55)\end{array}$ & 0.000 \\
\hline \multirow{2}{*}{ Constant } & $\begin{array}{c}1.385342 \\
(4.15)\end{array}$ & 0.000 \\
\hline
\end{tabular}

$\mathrm{t}$ student is indicated in brackets.

\section{Conclusion}

Our study shows that poor populations have recourse to the informal credit market to smoothing their consumption, and to cope with crises. Access to the informal credit market is closely related to social proximity of these poor populations. The access to a credit with a low rate of interest depends on their ability to constitute and maintain their social relationship, which may involve some expenditure on regular social contacts to keep this social relationship active. Hence, the high level of social expenses relative to income in poor households (Banerjee and Duflo, 2007) can find some justification.

Murdoch (2000) states that microfinance is a substitute for informal credit because the interest rates charged by moneylenders are higher than those of the microfinance institutions. 
Tsai (2004) finds evidence of four complementary factors between microfinance and informal finances in China and India, which contribute to strengthening the practice of informal finance in these countries. However, none of the analyses of informal finance shed light on the relationship between lenders and borrowers. If households fail to repay the debt, they cannot get loans from microfinance institutions. Moreover, our study took place in a context in which there were no sources of microfinance. In such a context, we can question the impact of introducing microfinance, notably as potential substitutes for informal credit, and their effects in terms of expenses for the poor. Assuming everything else remains equal in other respects, this could possibly reduce the expenses currently devoted to constituting social proximity. In this case, and according to this hypothesis, the introduction of microfinance could have an ambiguous effect. On the one hand, this would have the positive effect of reducing the weight of social expenses in the income of poor households, and on the other hand, possibly more randomly in the medium term, possibly by modifying social relationships within the villages.

Finally, our study shows that the asymmetrical information cannot explain by itself the value of interest rate on the informal credit market. Our study does not corroborate with the result of Ghosh and Ray (2001. The frequency of transaction is not associated with a decrease in interest rate. On the contrary, it exerts a positive effect on the interest rate. Social proximity exerts an influence which is thus not reduced to information asymmetry. It should rather be understood in a logic of rights and obligations of the relationship between individuals.

\section{References}

Aleem, I. (1990). Imperfect Information, Screening, and the Costs of Informal Lending: A Study of a Rural Credit Market in Pakistan. World Bank Economic Review, 4(3), 329349.

Banerjee, A. V. and Duflo, E. (2007). The Economic Lives of the Poor. Journal of Economic Perspectives, 21(1), 141-167.

Bardhan, P. and Rudra, A. (1978). Interlinkage of Land, Labour and Credit Relations. An Analysis of Village Survey Data in East India. Economic and Political Weekly, Annual Number, February 1978, 367-84.

Barslund, M. (2007). Microeconometric Application in Development Economics. PhD Thesis $\mathrm{n}^{\circ} 152$, University of Copenhagen.

Basu, P. (2005). A Financial System for India's Poor. Economic and Political Weekly, September 10, 2005.

Basu, K. (1991). Rural Credit Markets: The Structure of Interest Rates, Exploitation, and Efficiency. In: The Economic Theory of Agrarian Institutions, pp. 147-166. Oxford Scholarship Online Monographs.

Bell, C. (1990). Interactions between Institutional and Informal Credit Agencies in Rural India. World Bank Economic Review, 4(3), 297-327.

Bhende, M. J. (1986). Credit Markets in Rural South India. Economic and Political Weekly, 21(38/39), A119-A124.

Bhandari, R. (2007). The Role of Social Distance in Sharecropping Efficiency: The Case of Two Rice-Growing Villages in Nepal. Journal of Economic Studies, 34(4), 290-310.

Bhukuth, A. (2006). Debt Bondage in the Brokerage System: A Case Study of Sugarcane Migrants in the State of Tamil Nadu (India). International Journal of Development Issues, 5(1), 65-84, June 2006.

Bhukuth, A. Ballet, J. And Sirven, N. (2016). Bonded labour or What Else? A Case Study in Tamil Nadu India. Journal of International Development, first online October 212016. 
Bhukuth, A., Ballet, J. and Guérin, I. (2007). The Brokerage System and the Social Capital: the Formation of Debt Bondage in South India. Journal of Economic Studies, 34(4), 311-3212.

Bhukuth, A., Parthesarathy, R. and Venkatachellum, G. (2006). The Brokerage System in the Brick Kiln Industry in Tamil Nadu, India. Forum for Social Economics, 35(2), 55-74.

Bottomley (1963). The Premium for Risk as a Determinant of Interest Rate in Undeveloped Rural Areas. Quaterly Journal of Economics, 77(4), 637-647.

Bose, P. (1998). Formal-informal sector interaction in rural credit markets. Journal of Development Economics, 56(2), 265-280.

Braverman, A. and Guash, J. L. (1986). Rural Credit Markets and Institutions in developing Countries: Lessons for Policy Analysis from Practice and Modern Theory. World Development, 14(10-11), 1253-1267.

Braverman, A. and Stiglitz, J. (1982). Share Cropping and Interlinking of Agrarian Markets. American Economic Review, 72, 695-715.

Calvo-Armengol, A. and Jackson, M. O. (2005). Networks in Labour Market: Wage and Employment Dynamics and Inequality. Journal of Economic Theory, 132(1), 27-46

Chakrabarty, D. and Chaudhuri, A. (2001). Formal and informal sector credit institutions and interlinkage. Journal of Economic Behavior \& Organization, 46(3), 313-325.

Chavan, P. (2007). Access to bank Credit: Implication for Dalit Rural Households. Economic and Political Weekly, August 4, 2007.

Churchill and Guérin, I. (2004). Microfinance-led Strategies to Eliminate Bonded Labor. Paper presented to the Symposium "Microenterprise Solutions for the World's Poorest. December 8, Metropolitan College, New York City.

Diagne, A. (1999). Determinants of Household Access to and Participation In Formal and Informal Credit Market in Malawi. FCND Discussion paper $\mathrm{N}^{\circ} 67$, International Food Policy Research Institute. Washington D.C.

Fischer, C. (1982). To Dwell Among Friends: Personal Networks in Town and City. University of Chicago Press, Chicago.

Ghosh, P., Mookherjee, D. and Ray, D. (2000). Credit Rationing in developing Countries: An Overview of the Theory. In: A Reader in Development Economics. Mookherjee D. and Ray D. (eds.). London, Blackwell.

Ghosh, P. and Ray, D. (2001). Information and Enforcement in Informal Credit Market. Working paper University of British Columbia and New York University.

Giné, X. (2010). Access to Capital in Rural Thailand: An Estimated Model of Formal vs. Informal Credit. Working paper The World Bank, Washington D.C.

Granovetter, M. S. (1982). The Strength of Weak Ties: A Network Theory Revisited. In: Social Structure and Network Analysis. Marsden P. V. et Lin N (eds.). Beverly Hills, California, pp.105-130.

Granovetter, M. S. (1973). The Strength of Weak Ties. The American Journal of Sociology, $78,1360-1380$.

Guérin, I., Roesch, M., Venkatasubramanian, G., D’Espallier, B. (2012). Credit from Whom and for What? Diversity in Borrowing Sources and Uses in Rural South India. Journal of International Development, 24, S122-S137.

Guérin, I., Bhukuth, A. Parthesarathy, R., Venkatasubramanian, G. (2007). Labour in Brick Kilns: A Case Study in Chennai. Economic and Political Weekly February 17, 599-606

Guérin, I., Bhukuth, A., Marius-Gnanou, K., Servet, J. M. and Venkatasubramanian, G. (2004). Indebtedness, Vulnerability to Bondage and Microfinance. Report for the ILO (Social Finance Unit). Institut Français de Pondichéry, November 2004 
Guirkinger, C. (2008). Understanding the Coexistence of Formal and Informal Credit Markets in Piura, Peru. World Development, 36(8), 1436-1452.

Gupta, M. R. and Chaudhuri, S. (1997). Formal Credit, Corruption and the Informal Credit Market in Agriculture: a Theoretical Analysis. Economica, 64, 331-343.

Hoff, K. and Stiglitz, J. E. (1993). Imperfect Information and Rural Credit Markets: Puzzles and Policy Perspectives. In The Economics of Rural Organization: Theory, Practice, and Policy. K. Hoff, A. Braverman, and J. E. Stiglitz (eds), pp. 33-52. New York, Oxford University Press for the World Bank

Kirman, A. and Vriend, N. (2001). Evolving Market Structure: An ACE Model of Price Dispersion and Loyalty. Journal of Economic Dynamics and Control, 25(3-4), 459-502.

Kochar, A. (1997). An empirical investigation of rationing constraints in rural credit markets in India. Journal of Development Economics, 53(2), 339-371.

Krishna, A., Kapila, M., Pathak, S., Porwal, M., Singh, K. and Singh, V. (2004). Falling into Poverty in Villages of Andra Pradesh: Why Poverty Avoidance Policies are Needed. Economic and Political Weekly, June 17, 2004.

Krishna, A., Kapila, M., Porwal, M. and Singh, V. (2003). Falling into Poverty in a HighGrowth State. Economic and Political Weekly, 43(26), December 6, 2003.

Mahieu, F. R. (2001). Ethique économique. Fondements anthropologiques. Paris L'Harmattan.

Marsden, P. V. (1987). Core Discussion Networks of Americans. American Sociological Review, 52, 122-131.

Murdoch, J. (2000). The Microfinance Schism. World Development, 28(4), 617-629.

Nagarajan, G., Meyer, R. L. and Hushak, L. J. (1995). Segmentation in the informal credit markets: the case of the Philippines. Agricultural Economics, 12(2), 171-181.

Nisbet, C. (1967). Interest Rates and Imperfect Competition in the Informal Credit Market of Rural Chile. Economic Development and Cultural Change, 16(1),73-90.

Ramachandran, V. K. and Swaminathan, M. (2001). Does Informal Credit Provide Security? Rural Banking Policy in India. International Labour Office, Geneva.

Sriram, M. S. and Parhi, S. (2006). Financial Status of Rural poor: A Study in Udaipur District. Economic and Political Weekly, December 23, 2006.

Stiglitz, J. E. and Weiss, A. (1981). Credit Rationing in Market with Imperfect Information. American Economic Review, 71(3), 393-410.

Swaminathan, M. (1991). Segmentation, Collateral Undervaluation, and the rate of Interest in Agrarian Credit Market: Some Evidence from Two Villages in South India. Cambridge Journal of Economics, 15(2), 161-178.

Timberg, T. and Aiya, C. V. (1980). Informal Credit Markets in India. Economic and Political Weekly, 15(5/7), 279-302.

Tsai, K. (2004). Imperfect Substitutes: the Local political Economy of Informal Finance and Microfinance in Rural China and India. World Development, 32(9), 1487-1507.

Van Bastelaer, T. and Leathers, H. (2006). Trust in Lending: Social Capital and Joint Liability Seed Loans in Southern Zambia. World Development, 34(10), 1788-1807

Wahba, J. and Zenou, Y. (2005). Density, Social Networks and Job Search Methods: Theory and Application to Egypt. Journal of Development Economics, 78, 443-473.

Zeller, M. (1994). Determinants of Credit Rationing: A Study of Informal lenders and Formal Groups in Madagascar. World Development, 22(12), 1895-1907. 